\title{
The Impact of the News Frames on Report of the 2020 Pandemic in China's National Media
}

\section{Hai Tang* Zhe Zhu Lihong Qi}

School of Foreign Languages, Wuxi Taihu University, Wuxi, Jiangsu, 214063, China

\section{ARTICLE INFO}

Article history

Received: 17 February 2021

Revised: 25 February 2021

Accepted: 15 October 2021

Published Online: 30 October 2021

\section{Keywords:}

News frames

Frame theory

Established media

2020 epidemic

Disaster news

\begin{abstract}
News frames is a general application of the Frame Theory in journalistic practice, and the setting of the Frame Theory in news media, to some extent, may make the news agency have more choices of the topics, more channels of the report, and more impacts on readers and audiences. It is for this reason that news media are very interested in setting up their news frame to guide their reportage. It won't be surprised that when important affairs took place, the media set a theme for their coverage; while at the same time, audiences recognized that they are allowed to know the facts as well to evaluate the events properly. The coverage of disaster news is one of the concrete examples. However, when reading the reportage framework of the news in China, it can be seen that media would be likely to set similar frames for the focus of the report, and this potentially created complexity and difficulty in analyzing disaster news events in terms of content classification, reporting form, and news-making on effectiveness. The outbreak of the 2020 COVID-19 gathered media to work on a centralized proposal - anti-epidemic, so that textual, audio-visual contents and other forms of reporting show a diversified perspective for disaster news. This reporting form is a new challenge for Chinese news media, reflected in their practice on how Chinese government and people fought against the virus, how Chinese medical community dispatched their team to assist COVID-19 fight, and how Chinese media responded to the vilification of foreign media during that period. This paper takes three established media Hubei Daily, CCTV and China Daily as examples for an in-depth analysis.
\end{abstract}

place in a sudden, with features of being unpredictable, changeable, live or fleeting. Often when a disaster event occurs, media coverage becomes rather important. They play a role in appeasing the public, questioning authority and undertaking social functions ${ }^{[2]}$. It is fair to say that Chinese media have learned a lot of lessons through reporting on 2003 SARS incident, and their reportage on disaster events becomes more open and transparent.

However, if we take an in-depth look at the Chinese media reportage, it won't be difficult to find that newsmaking from the media, still, is lack of common consensus

*Corresponding Author:

Hai Tang,

School of Foreign Languages, Wuxi Taihu University, Wuxi, Jiangsu, 214063, China;

Email: carlatube@qq.com 
guided by the news frame, leading to a lake of rationality commented by the public or a lack of continuity practiced by journalists so that a total public credibility could be missing ${ }^{[3]}$. But the coverage of the epidemic in 2020 has greatly strengthened the credibility of the Chinese media, and one of the important reasons might be that, the media start to know how to use the Frame Theory to guide their reports, and to guide the direction of public opinions.

We all remember that at the beginning of 2020, an outbreak of COVID-19 widespread media attention both at home and abroad. Domestic media used multiple means, through a variety of their news channels, to actively participate in reporting of the pandemic events. What are the focus parts of their reporting? And how the pandemic impact on their own news frames of the news media? By raising the two questions, this paper aims to take three national media CCTV, Hubei Daily and China Daily as representatives for an explanation.

The setting of the structure of this paper is divided into four parts; besides the above taking the role of an introduction, the next section will focus on the importance of the Frame Theory and how different media use it in practice. The third section takes China's three media, CCTV, Hubei Daily and China Daily as specific examples to show the news contents the three media have disseminated, while it also argues that not the contents itself but a centralized proposal of the news frame as the base and the keystone for guiding their reports to win public credibility during the outbreak. The last section is in relation to conclusion. It again argues that, in fighting against the COVID-19 epidemic, how important for media to set a central proposal of news frame, to some extent, it is the news frame that has offered more possibilities to increase China's discourse power.

\section{Framing Theory, Frame-centered Representation and the Use of News Frames in Doing Disaster News}

The Frame Theory was established by Marvin Lee Minsky, and it soon becomes an important method used in qualitative studies. On one hand, it focuses on the study of psychology, for instance, "cognitive science" is used as one of the frameworks. "Topic-setting" is a familiar example and is used to ask students to discover differences or specificities from the existing resources. The process of thinking about the topic may rely on a group of students, their cognition in understanding the keywords, the phenomenon, or the emphasis in relation to the topic. As Cai Shushan addressed:

The birth of cognitive science has provided a framework for the integration of multiple disciplines and heralds a new area of scientific synthesis ${ }^{[4]}$.

On the other hand, the focus of the Frame Theory is on sociology studies. Erving Goffman borrowed the term "frame", which was coined by Gregory Bateson, but he then expounded the theory in communication studies.

From an anthropological perspective, human interaction is composed of multiple factors, such as shared cognition and identity, environment for communication and so on, all of which can be the frame used to determinate the quality of communication ${ }^{[5]}$.

Obviously, Goffman opened a door for scholars to use the Frame Theory for working on communication studies. Then ${ }^{[6]}$ took message as the frame to analyze people's health behaviors. And ${ }^{[7]}$ analysed the attachment behaviors of tourists by setting the goal as the frame for their study.

The Frame Theory has been used frequently in media studies in recent years. For instance, news frame is an application of Frame Theory to guide journalistic practice in media. It is a fundamental outline for media organizations to collect news sources, edit news reports and disseminate them to the public ${ }^{[8]}$.

Research on the news frame in China focuses on the function of the media in making news such as big media set frames for political communication; or medical journals set frames for delivering medical sources. Specifically, the setting of the news frames is also applied by media to do comparative studies such as domestic news vs. international report ${ }^{[9]}$, or how a genre-based event deconstructed by different media ${ }^{[10,11]}$. In this sense, the news frame shows journalistic strategies and the value of the report cognized by the media.

The concept of "News Frames" is used in academia to study how the media report a particular event. In this sense, selecting topics and editing messages are very important for journalistic work. In addition, much of the attention shall be paid on balancing the contents; the encoding of the message shall be satisfied with the one decoded by readers. In other words, comments, attitudes, and beliefs of the media may impact on audiences, to some extent ${ }^{[10]}$.

Talking about genre-based event, disaster news shows its particularity. Its harmfulness, danger, suddenness and higher sensitivity always force a speedy reportage from the media, so as to make timely reporting to meet the public needs, and allow the public to know the truth and to reduce the fear.

Chinese media have made great progress in reporting of disaster news in recent years. For example, when the Wenchuan earthquake occurred at 9:19 PM on August 8, 2017, its local TV station immediately published the event 
${ }^{[9]}$. At the end of October 2019, the Paper.cn lively reported a bridge collapse event in Wuxi ${ }^{[12]}$. At the beginning of 2020, COVID-19 shown as strong virus and it acted as the biggest disaster news in China. Chinese media used an integrated news frame to report on the event, reflected in the process of how China fight against the epidemic, how China prevents it from wide spreading, and how China make great measures to save lives, as Shen Yurou argued:

The COVID-19 epidemic gives priority to media for fulfilling their discursive power. As a consequence, there shouldn't be only one voice, or few media to control the information. Instead, media shall set the frame for working on their reportage, by providing sufficient and accurate information to comfort the public ${ }^{[10]}$.

It can arguably say that, how media report on disaster news will potentially affect the emotion of the audiences. In the following section, the focus of the paper will be given to three established media in China: Hubei Daily, CCTV and China Daily; they will be used as representative news media who used the Frame Theory in reporting on the pandemic. Then, what are the features of their reports?

\section{Analyses of the Media Report on the Pandemic in 2020}

From January to August 2020, lots of news organizations involved in reporting on the pandemic events. 21 of them were impressed by the public, according to Yidianzixun ${ }^{1} .17$ of the agencies were related to the introduction and the updated information on the outbreak, including recent deaths, cured patients, and results of new treatment ${ }^{2}$. Around $47 \%$ of the articles focused on the prevention of the virus, and reposted articles were over 100,000 . Average $48 \%$ of the contents concentrated on the sides such as hygienic knowledge, the effect of the pandemic on both daily life and national economy and the other ${ }^{3}$.

This paper will choose 3 of the 21 news-media, Hubei Daily, CCTV, and China Daily, with both discourse and content analyses to see how the three national media set up their news frame for their specific reportage. The

1 Chuanmeijiangwen (29/02/2020). Official Investigation: These Media have Impressed the Public during the Outbreak (in Chinese). Available at http://www.yidianzixun.com/article/0OkJW14L. [Accessed on 04/20/2021].

2 Zhangmenmiao (30/01/2020). Reportage of the Epidemic in Chinese Mainstream Media. Available at http://www.shopmall.org.cn/a/kuaixun/ redianzhuanti/2020/0130/1208.html. [Accessed on 18/11/2020].

3 Dongtaidacaikao (02/02/2020). Analyses of the Epidemic Reportage on 13 National Media in China. Available at https://baijiahao.baidu. $\mathrm{com} / \mathrm{s}$ ? id=1657393394865526960\&wfr $=$ spider $\&$ for $=\mathrm{pc}$. [Accessed on 18/11/2020]. timeline of the research was in 3 months, from March to June in 2020.

\section{Hubei Daily: Much of the Attention was Paid on Humanistic Care}

Hubei Daily was founded on July 1, 1949. It is an official newspaper of the Hubei Province. The newspaper publicizes news and information orientating the development of Hubei province in industrial, agricultural, scientific areas, highlighting role models on all fronts.

According to cnhubei.com, during the outbreak, Hubei Daily published more than 60,000 reports, and the newspaper launched more than 1,100 special editions, along with 60 more columns; it posted 40 more pictures regarding topics to pandemic and attracted more than 70 series of comments ${ }^{4}$.

[Hubei Daily] This might be a war without smoke, and in Wuhan, everyone is trying to fight against the virus and protect life. Some people even have to stay awake all night. They are doctors, nurses, drivers, cleaners, receptionists, etc.; they might be very ordinary, but without them, the city of Wuhan won't be safe. (02/03/2020, reported by Deng Wei and Chen Peng) ${ }^{5}$

[Hubei Daily] The Hubei Government recently assessed 14 people who died in the prevention and control of the COVID-19 as the first martyrs, according to official documents. (02/04/2020, reported by Wuhan, Xinhua Net) ${ }^{6}$

[Hubei Daily] On the May Day Holiday, President Xi Jinping wrote back to employees of Zhengzhou Yuanfang Group on April 30, sending greetings to all the people in China. (01/05/2020, reported by Beijing, Xinhua Net) ${ }^{7}$

From reading the paper we can see that, from March to May 2020, Hubei Daily reported the outbreak in the form of a doctor-patient relation, with medical-team assistance, and experts' guidance. Also, the newspaper

4 See Hubei Daily Won the Prize Again (13/12/2020). Available at https://www.sohu.com/a/437949928_119861. [Accessed on 07/02/2021]. 5 See Deng, W. and Chen, P. (02/03/2020). Working Day and Night to Fight Against the Virus: Approaching the Great People in Wuhan (in Chinese). Available at https://epaper.hubeidaily.net/pc/ content/202003/02/content_22334.html. [Accessed on 04/02/2021].

6 See Wuhan, Xinhua Net. (02/04/2020). The 14 Victims in COVID-19 Epidemic in Hubei Were Assessed as the First Martyrs (in Chinese). Available at https://epaper.hubeidaily.net/pc/content/202004/03/ content_24652.html. [Assessed on 04/2021].

7 See Beijing, Xinhua Net. (01/05/2020). President Xi Jinping Wrote back to the Workers of Zhengzhou Yuanfang Group to Encourage them to Overcome difficulties (in Chinese). Available at https://epaper. hubeidaily.net/pc/content $/ 202005 / 01 /$ content_28273.html. [Accessed on 04/02/2020]. 
showed much of the respect to ordinary people who sacrificed their personal comforts during COVID-19 outbreak. The keywords or the key phrases like "the moment of the lockdown", "saving people's life", and "positive consequences of the anti-pandemic" were used frequently to explore how Wuhan residents fought against the COVID-19. And, President Xi Jinping's greetings and encouragements also highlighted the achievements of Wuhan people and their ways of anti-epidemic. In short, the reports conveyed a humanistic care to the public, by stressing a societal function of the media as news frame. In other words, the news frame set by Hubei Daily is not only on the outbreak, or understanding of the outbreak, but is also on addressing the great anti-pandemic spirit among doctors, patients and Wuhan residents, thus, the reportage in 2020 showed a great love for life in Hubei Daily.

\section{CCTV: The Content of the Report Focused on Maintaining the Image of China}

CCTV (China Central Television) is the national television station of People's Republic of China. It was established on May 1, 1958. CCTV has been talking the role of disseminating important news since its establishment in all directions, such as news information, socio-cultural life, entertainment, high-tech and so on so forth.

From the announcement of the outbreak in 2020, major news platforms of the CCTV have never been interrupted by their linkage to disaster news reportage. For example, a popular column of CCTV - "News $1+1$ ", it not only invited Zhong Nanshan, Wang Chen, Li Lanjuan and other experts to explain the virus, but also it connected with local officials to discuss issues relating to health crisis so as to push updated information open to the public ${ }^{8}$.

[CCTV News] From today onward, CCTV will consistently broadcast its prompt commentary on "Building a Strong Public Health System in China. $(03 / 06 / 2020)^{9}$

\section{[CCTV News] The National Health Commission} today informed that as of June 9, 31 provinces have reported 55 confirmed cases, of which 54 were imported from abroad, and 5 new cases were asymptomatic coronavirus carriers; among the

8 See What Have CCTV and Other Official Television Stations Done during the outbreak? Available at https://www.sohu.com/ a/370273859_100097343. [Accessed on 07/02/2020].

9 The original context can be seen on https://tv.cctv.com/2020/06/03/ VIDEwdcYtgWPtIrWwJz7IbQ1200603.shtml?spm=C53156045404. PIxDNolGigyV.0.0 (What does the Result of Covid-test Mean to Wuhan?) [Accessed on 07/02/2020]. existing confirmed cases imported from abroad, there have been no further infections within 15 days, and patients are gradually recovering under clinical observations. $(10 / 06 / 2020)^{10}$

[CCTV News] CCTV will broadcast its prompt commentary on the policy of "Ensuring the Safety of people's Lives in the First Place" in China. $(29 / 06 / 2020)^{l l}$

The above examples are excerpted from CCTV's News Broadcasting Programme. From reading the contents we can see that, within the month of June 2020, CCTV News Broadcasting aired relevant outbreak information, while differently from Hubei Daily, it related to how government-led anti-pandemic policies and activity executed, and how significance the implementation of the policy benefits Chinese people. A series of important information such as "no deaths but an increasing number of cured patients", and "discussion certain approaches to save people's lives" indicate a strong signal of Chinese government in leading China to the positivity in emergency rescue and disaster relief.

\section{China Daily: Re-emphasis of the Dominant Function of the "Mouthpiece Theory" on Chinese Media}

China Daily is an English-based newspaper founded in 1981. It is an important window for Chinese people to understand the world, as well, it allows the world to understand China. During the outbreak, China Daily published a series of reports focusing on telling real stories of China, giving full play to the strategic supporting role of "the mouthpiece" in China's media management.

[China Daily] We are deeply shocked by your report on March 29 as China's anti-epidemic efforts have been seriously ignored, discrediting China's great contribution to the World Health Organization. The Chinese Embassy in the United Kingdom has expressed its dissatisfaction with the British Government and requested clarification on report and statements. $(08 / 04 / 2020)^{12}$ 引用

10 The original context can be seen on https://tv.cctv.com/2020/06/09/ VIDE8iWUngyWOWLtjGeFo3UW200609.shtml?spm=C53156045404 PIxDNolGigyV.0.0 (How to Improve a Public Health Emergency System?) [Accessed on 02/07/2020].

11 The original context can be seen on https:/tv.cctv.com/2020/06/29/ VIDEqP9vlVmJilLPiZ2KKqE3200629.shtml. (With Tens of Millions of Confirmed Cases outside China, is it Going to be Out of Control?) [Accessed on 02/07/2020].

12 The original content can be seen on http://cn.chinadaily.com.cn/ a/202004/08/ WS5e8cfc9ca310395ca8f743cc.html (Liu Xiaoming. Don't Blame China, We Want to Beat This Together). [Accessed on $02 / 11 / 2021]$.

DOI: http://dx.doi.org/10.26549/jetm.v5i2.6441 


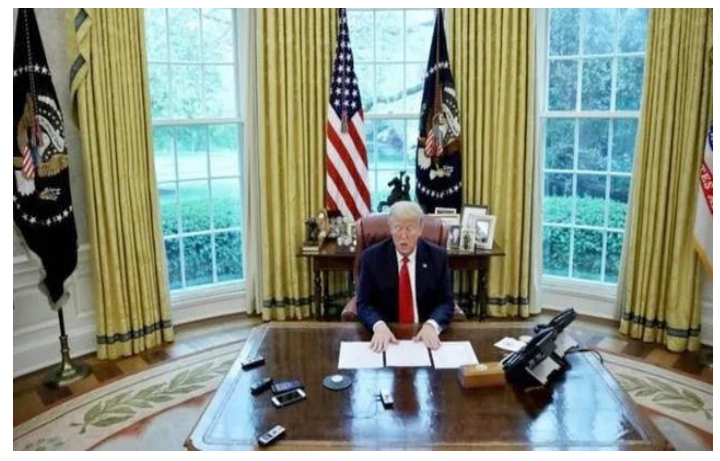

Figure 1. Previous US president Donald Trump

Source: https://baijiahao.baidu.com/s?id=166540631874173772 $7 \& w f r=$ spider $\&$ for $=p c$

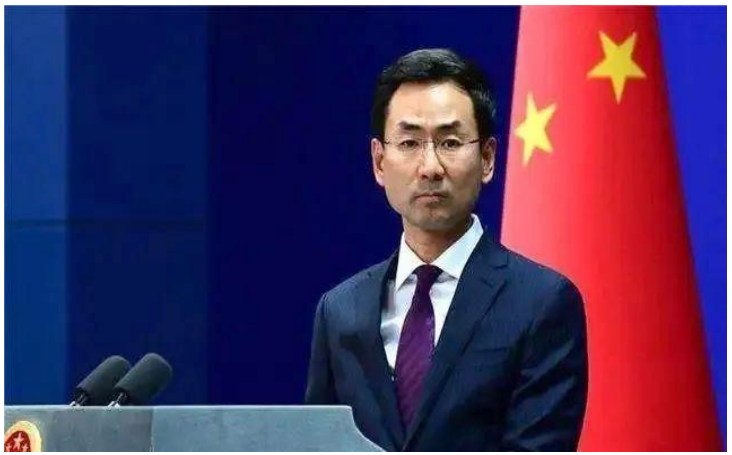

Figure 2. Spokesman Geng Shuang on China's Foreign Press Conference

Source: https://baijiahao.baidu.com/s?id=166540631874173772 $7 \& w f r=$ spider $\&$ for $=$ pc

[China Daily] WASHINGTON (Reuters) President Donald Trump said on Wednesday he believes China's handling of the coronavirus is proof that Beijing will do anything they can to make him lost his re-election bid in November. (Cited in Steve Holland)

...

In response, our spokesman Geng Shuang said at a regular Foreign Ministry Press Conference on April 30 that China had no interest in interfering in the U.S. election. $(30 / 04 / 2020)^{13}$

The above two examples were reported by China Daily in 2020. From the first contexts we see that, as the Sunday Express in Britain have misrepresented China's success in fighting against the epidemic, Ambassador Liu Xiaoming gave the media an immediate counter-attack. The second

13 The original content can be seen on http://cnnews.chinadaily.com.cn/ /a/202004/30/WS5eaa915ba310eec9c72b6854.html (Trump Says, China Will Try Harder to Defeat the Election of the U.S., Foreign Ministry of China: We Have No Interest at All, reported by Wu Yuanchun). [Accessed on $03 / 11 / 2021]$. report illustrated Donald Trump's usual style, by imposing his nonsense on western media and his sinister willingness on China. However, Trump was constantly hit by spokesmen from China's Foreign Ministry and the state media in China (see Figure 1 and 2).

Judging from the coverage of the outbreak, it is ironically to say that western media reporting of disaster news does not seem to own the freedom that they used to have, and this partially has caused a prevention of the disease towards chaos. While the case of the China Daily emphases on "group images" built by China, the rescue teams, the achievement, and the arguing with the West, are efforts at all levels of Chinese government to contest anti-Western rhetoric and politics; by paying more attention to a stable and coordinated development, China's collectivism-based value orientation show certain advantages during the outbreak.

\section{Conclusions}

Chinese media in the coverage of the outbreak in 2020, reported the events regarding both "mouthpiece" and "societal" function of the media, with coordinated and unified characteristics ${ }^{[13]}$. It is a stabilized social order with a secure national image of China that has guided Chinese media a fundamental outline to report on the disaster news.

Under such a settled news frame, the media coverage of the COVID-19 pandemic would focus more on what a positive and determined approach supposed to be ${ }^{[9]}$. As seen from the above media, Hubei Daily reported the treatment by medical staffs, CCTV broadcasted in a timely manner to eliminate potential tragedies of the disaster, and China Daily worked on the attack from the West, all of which are respective news frames set by the three media, disseminating focused events to the public.

The temporary victory of the pandemic in China certainly has aroused the Western media to rethink the theme of reporting on disaster news, whether it shall be reflected only in its humanitarian or instructive scales, to a certain extent? As the ultimate goal of reporting disaster news is to awake people from understanding the nature towards respecting the nature, it also raises a severe question to China or Chinese media, when is the plan of developing the domestic green industry? Or what is the strategy to essentially protect an ecological environment? This might be the new news frame set for China, Chinese government, Chinese people especially Chinese media to think and to do for global development in post-pandemic times. 


\section{References}

[1] Ding, H. (2016). Research on the Strategies of Report on Disaster News in the 2005-2015 China's Journalism Awards (in Chinese). Chuanbo Yu Banquan, 11, pp. $15-17+22$.

[2] Yang, G. (2015). Construction of Public Consensus on Reading Disaster News (in Chinese). Youth Journalist, 24, pp.47-48.

[3] Xu, X. D. and Liu, Y. O. (2015). A Study of News Reportage Patterns on Disaster Events (in Chinese). Journalism Lover, 9, pp.18-20.

[4] Cai, S. S. (2009). On the Integration and Development of Psychology and Logic within the Framework of Cognitive Science, Social Sciences in China, 2, pp.93-107.

[5] Liu, Q. (2015). The Frame Theory: Concept, Sources and Methodology (in Chinese). China Publishing Journal, 8, pp.19-24.

[6] Yang, M. Q., Zhao, Y. Q., Song, S. J. and Zhu, Q. H. (2020). Origin, Application, and Development of Message-Framing Theory in Foreign Health Behavior Research (in Chinese). Journal of China Society for Scientific and Technical Information, 39 (6), pp. 662-674.

[7] Ren, J. J., Li, X. Y., Sheng, C. and Gao, Y. (2020). A Study of Attachment Behaviors of the Tourists from the Perspective of the Goal-Framing Theory: The Analyses of the E-commerce Sites of Travel Agencies. Journal of Taishan University, 42(4), pp. 103108.

[8] Yu, Y. (2020). Research of the Disaster News on WeChat from the Perspective of the Frame Theory (in Chinese). Home Drama, Vol. 367(31), pp.201-3.

[9] Zeng, Y. M. (2020). A Comparative Study of Disaster News Reportage between Chinese Media and Western Media (in Chinese). Journal of Communication University of Zhejiang, Vol. 25 (4), pp.83-8.

[10] Shen, Y. R. (2020). Using the Frame for Reporting during the Outbreak in Official and Unofficial Media: A Comparative Study of Xinhua Net and Life Weekly (in Chinese). News Tribune, 34(4), pp.83-86.

[11] Zhang, S. X. (2018) The Evolution and Development of Reporting Mode on Disaster News in the Context of the New Media (in Chinese). Public Communication of Science \& Technology, 10 (13), pp.20-21.

[12] Yin, Y. D. (2019). From Integration of Genre-based News Towards the News of Integration: A Case Study of the Bridge Collapse in Wuxi (in Chinese). Journalism Communication, 21, pp.49-50.

[13] Ma. Q. and Yang, X. C. (2019). The Value Concept and Practical strategy of Reporting on Disaster News (in Chinese). Hubei Social Sciences, 5, pp.184-8. 